\title{
MENGUJI KONSEP PERTANGGUNGJAWABAN PIDANA KORPORASI
}

\author{
Adriano \\ adriano@yahoo.co.id \\ Hakim Pengadilan Tindak Pidana Korupsi Bandung
}

\begin{abstract}
An entity, either a legal or the non legal "entity" which all were discussed in the same outline of corporate crime responsibility. It was often, though, in several laws aside from the Penal Code of Indonesia (KUHP), both in Criminal Law and Administrative Law with criminal sanction, that corporate is defined as a collection of organized people and or wealth, either as a legal or the non legal entity. The definitions in those laws are really different from those of law experts, especially those of criminal law who basically identify corporate as a legal entity, however the same is not true for those of the non legal entity. Such differences of the legal and non legal entities would bring their own legal consequences, therefore they could not and would not be treated the same referring to corporate criminal responsibility.
\end{abstract}

Keywords: corporate criminal responsibility, legal entity, non legal entity.

\begin{abstract}
Abstrak
Sebuah entitas, baik hukum badan hukum atau non kesemuanya dibahas dalam garis tanggung jawab yang sama yaitu kejahatan korporasi. Hal ini adalah hal yang pasti sekalipun, dalam beberapa undang-undang selain dari Kitab Undang-Undang Hukum Pidana Indonesia (KUHP), baik di ranah Pidana hukum maupun hukum Administrasi semuanya berkaitan dengan sanksi pidana, perusahaan yang didefinisikan sebagai kumpulan orang-orang yang terorganisir dan atau kekayaan, baik sebagai hukum atau bukan badan hukum. definisi dalam hukum itu benar-benar berbeda dari para ahli hukum, khususnya pidana hukum yang pada dasarnya mengidentifikasi perusahaan sebagai badan hukum, namun hal yang sama tidak berlaku untuk orang-orang dari badan non hukum. perbedaan tersebut dari badan hukum legal dan non akan membawa konsekuensi hukum mereka sendiri, karena itu mereka tidak bisa dan tidak akan diperlakukan sama, hal ini dikarenakan perbedaan bentuk pertanggung jawaban dari masing-masing pihak yang berbeda.
\end{abstract}

Kata kunci: tanggung jawab kejahatan korporasi, badan hukum, non badan hukum. 


\section{Pendahuluan}

Terdapat belasan undang-undang produk lembaga legislasi negara ini yang menentukan dan mengatur tentang pertanggungjawaban pidana dalam hal terjadi perbuatan-perbuatan pidana tertentu yang diatur di luar Kitab Undang-Undang Hukum Pidana (KUHP) yang berkaitan atau dipandang dapat dilakukan dan dipertanggungjawabkan oleh korporasi.

Fenomena tersebut di Indonesia telah muncul dalam beberapa tahun dasawarsa terakhir ini, dimana kebanyakan para pakar hukum terutama hukum pidana mengklasifikasikan dan menyebutnya sebagai "kejahatan korporasi", untuk menggambarkan perbuatan-perbuatan pidana tertentu yang oleh undang-undang tertentu diluar KUHP dianggap dapat dilakukan dan dipertanggungjawabkan oleh suatu badan, baik yang berbentuk badan hukum maupun tidak berbadan hukum sebagai suatu korporasi. Istilah kejahatan korporasi (corporate crime) seringkali dikaitkan dengan kejahatan yang berkategori inkonvensional dalam konteks white collar crime, organization crime, orgazined crime, crime of business, syndicate crime yang secara umum dimaksudkan sebagai suatu kejahatan yang bersifat organisatoris dengan bermuara pada motifmotif keuntungan ekonomi, yang tercermin dari adanya kontradiksi antara tujuan korporasi dengan kepentingan berbagai pihak seperti kompetitor (pesaing), buruh, konsumen, masyarakat dan negara. ${ }^{8}$ Sehingga tidak mengherankan jika kejahatan ini dengan cepat menyebar dan berdampak luas serta amat merugikan.

Penggunaan istilah korporasi dalam rangkaian kata "kejahatan korporasi" untuk menggambarkan suatu badan (baik yang merupakan badan hukum maupun yang bukan badan hukum) sebagaimana diuraikan di atas menurut hemat penulis justru menimbulkan persoalan mendasar yang bukan saja mengenai persoalan subyek hukum, akan tetapi juga lebih mendalam lagi yakni menyangkut masalah pertanggungjawaban pidananya itu sendiri baik ditinjau dari sudut pandang doktrin dalam ilmu hukum, norma hukum yang mengatur mengenai badan hukum dan badan yang bukan badan hukum, maupun dalam kaitannya hukum sebagai suatu sistem.

Persoalan mengenai subyek hukum secara ringkas dapat disebutkan bahwa selama ini doktrin dalam ilmu hukum telah mengajarkan bahwa subyek hukum sebagai pengemban hak dan kewajiban dalam masyarakat hukum. Subyek hukum terdiri dari orang perorangan dalam arti manusia (natuurlijke person) dan badan hukum (rechtspersoon) yang keduanya dalam konteks hukum sering disebut sebagai orang, sehingga dengan gamblang terlihat adanya kejanggalan bahwa badan yang bukan badan hukum yang nota bene juga bukanlah subyek hukum didalam berbagai undang-undang di luar KUHP itu dapat pertanggungjawabkan secara pidana, yang artinya dapat dituntut dan dipidana.

Persoalan mendasar sebagaimana penulis uraikan di atas, jelas akan membuat suatu ketentuan dalam undang-undang yang dibuat dengan susah payah dan menelan biaya miliaran

8 Yesmil Anwar dan Adang, Kriminologi, Bandung: Refika Aditama, 2010, h. 241-242. 
rupaih menjadi tidak bisa diterapkan. Sebagai contoh konkretnya adalah ketentuan dalam Pasal 1 angka 21 Undang-Undang Nomor 35 Tahun 2009 tentang Narkotika (UU No. 35/2009), menentukan bahwa : "Korporasi adalah kumpulan terorganisai dari orang dan/atau kekayaan, baik merupakan badan hukum maupun bukan”. Selanjutnya Pasal 130 ayat (1) dari UU No. 35/2009 tersebut menentukan bahwa: "Apabila tindak pidana sebagaimana dimaksud dalam ayat (1) dilakukan oleh korporasi, dipidana denda paling banyak Rp. 5.000.000.000,- (lima miliar rupiah)".

Undang-Undang Nomor 31 Tahun 1999, sebagaimana telah diubah dengan UndangUndang Nomor 20 Tahun 2001 tentang Perubahan atas Undang-Undang Nomor 31 Tahun 1999 tentang Pemberantasan Tindak Pidana Korupsi (UU Tipikor), Pasal 1 angka 1 menentukan bahwa Korporasi adalah sekumpulan orang dan atau kekayaan yang terorganisasi baik merupakan badan hukum maupun bukan badan hukum". Lebih lanjut Pasal 20 ayat (1) dari undang-undang tersebut menentukan: "Dalam hal tindak pidana korupsi dilakukan oleh atau atas nama suatu korporasi, maka tuntutan dan penjatuhan pidana dapat dilakukan terhadap korporasi dan atau pengurusnya.

Menyimak contoh dari ketentuan-ketentuan sebagaimana tersebut di atas khususnya mengenai badan yang bukan badan hukum, terbersit dalam benak penulis: bagaimana mungkin sesuatu yang bukan subyek hukum diperlakukan sama seolah-olah ia adalah subyek hukum, yang artinya "sesuatu itu" bukan sebagai penyandang hak dan kewajiban yang diembankan oleh hukum namun ia dipertanggungjawabkan dalam hukum, dan bahkan dijatuhi sanksi hukum (dalam hal ini sanksi pidana), dan ironisnya terdapat belasan undang-undang yang tergolong baru yang memuat ketentuan-ketentuan serupa dengan ketentuan sebagaimana contoh diatas.

Menurut penulis, kebijakan legislasi dalam merumuskan suatu ketentuan peraturan perundang-undangan pidana tertentu diluar KUHP, dan dalam peraturan perundang-undangan administrasi yang bersanksi pidana khususnya yang menyangkut pertanggungjawaban pidana terhadap suatu badan semestinya harus memperhatikan prinsip-prinsip hukum yang mendasari keberadaan badan tersebut. Prinsip-prinsip hukum yang penulis maksud adalah adanya karakteristik-karakteristik tertentu yang menyangkut keberadaan suatu badan, baik itu badan hukum maupun badan yang bukan badan hukum yang jauh sebelumnya memang telah difikirkan, tertanam dan tertata sedemikian rupa dengan nalar dalam doktrin serta diatur dengan tegas dalam hukum perdata positif, sehingga apabila pembuat kebijakan legislasi berkehendak mengadopsi dan memasukannya kedalam ranah ketentuan hukum pidana, maka karakteristikkarakteristik yang melekat pada masing-masing badan tersebut haruslah menjadi pakem yang wajib dipedomani agar ketika undang-undang tersebut diberlakukan tidak saling bertabrakan antara satu dengan lainnya sehingga tidak terjadi disharmoni dalam pengaturan, dan keadilan, kemanfaatan serta kepastian hukum akan lebih terjamin. 


\section{Batasan Korporasi}

Menurut Sutan K Malikoe Adil ${ }^{9}$ kata korporasi secara etimologis berasal dari kata “corporatie” (Belanda), “corporation” (Inggris), “corporation” (Jerman) yang berasal dari kata "corporatio" dalam bahasa Latin yang kata kerjanya adalah "corporare”, dimana kata corporare itu sendiri berasal dari kata "corpus" yang berarti memberikan badan atau membadankan, yang dengan demikian sebenarnya "corporation" itu berarti hasil dari pekerjaan membadankan, atau dengan kata lain badan yang diperoleh karena perbuatan manusia sebagai lawan dari badan manusia yang terjadi menurut alam.

Berbicara mengenai korporasi sekalipun dalam konteks hukum pidana, tidak akan pernah bisa lepas dari bidang hukum perdata karena memang yang menjadi dasar berdirinya korporasi diatur dan masuk dalam lingkup hukum perdata, berkaitan dengan itu Dwidja Priyatno tegas mengatakan bahwa:

Batasan pengertian atau definisi korporasi, erat kaitannya dengan masalah dalam bidang hukum perdata. Sebab pengertian korporasi merupakan terminologi yang berkaitan erat dengan istilah badan hukum (rechtspersoon), dan badan hukum itu sendiri merupakan terminologi yang erat kaitannya dengan bidang hukum perdata. ${ }^{10}$

Hal senada juga disampaikan dengan tegas oleh M. Arief Amrullah yang menuliskan bahwa:

Berbicara mengenai korporasi, tidak dapat dilepaskan dari sudut pandang hukum perdata, karena pada awalnya memang hukum perdata yang banyak berhubungan dengan masalah korporasi sebagai subjek hukum. Dalam hukum perdata perkataan orang berarti pembawa hak atau subyek hukum (subjectum juris). Akan tetapi, orang atau manusia bukanlah satu-satunya subjek hukum (natuurlijke person), karena masih ada subjek hukum lain yang menurut hukum dapat memiliki hak-hak dan melakukan perbuatanperbuatan hukum seperti seorang manusia, mempunyai kekayaan sendiri dan dengan perantaraan pengurusnya dapat digugat dan menggugat dimuka sidang pengadilan. Subjek hukum yang dimaksud yaitu badan hukum (rechtspersoon), artinya orang yang diciptakan oleh hukum. Badan hukum atau korporasi itu misalnya, suatu perkumpulan dagang yang berbentuk perseroan terbatas, perserikatan orang atau yayasan, atau bentubentuk korporasi lainnya. ${ }^{11}$

Pendapat M Arief Amrullah tersebut memperjelas bahwa memang korporasi yang dimaksud dalam konteks kejahatan korporasi dalam hukum pidana adalah juga korporasi sebagaimana dimaksud dalam hukum perdata. Telah disinggung di atas bahwa korporasi adalah badan hukum (rechtspersoon) yang merupakan salah satu dari subyek hukum, disamping manusia (natuurlijke person), atau dengan kalimat yang lain dapat dikatakan bahwa manusia (natuurlijke person) dan badan hukum (rechtspersoon) oleh hukum ditetapkan sebagai subyek hukum, yakni sebagai pengemban hak dan kewajiban.

Jowitt dan Walsh sebagaimana dikutip oleh Yesmil Anwar dan Adang, mengatakan: Corporation, a succession or collection of persons having in the estimation og the law an

$9 \quad$ Soetan K. Malikoe Adil, Pembaharuan Hukum Perdata Kita, Jakarta: Pembangunan, 1955., h. 83.

10 Dwidja Priyatno, Kebijakan Legislasi Tentang Sistem Pertanggungjawaban Pidana Korporasi di Indonesia. Bandung: Utomo, 2009, h. 12.

11 M. Arief Amrullah, Kejahatan Korporasi, Malang: Banyumedia Publishing, 2004, h. 201. 
existence and right and duties distinct from those of the individual persons who from it to from time to time. (artinya: Korporasi, suatu rangkaian atau kumpulan orang-orang yang memiliki estimasi eksistensi dan hak-hak dan kewajiban hukum yang berbeda dari individu dari waktu kewaktu). ${ }^{12}$ Lebih jauh, dalam Jowitt's Dictionary of English Law dijelaskan bahwa:

A corporation is also known as a body politic. It has a fictious personality distinct from that of its members." Artinya suatu korporasi adalah juga dikenal sebagai badan politik. Korporasi memiliki karakter fiktif yang berbeda dari para anggotanya. Pengertian korporasi tersebut di atas, kemudian diperjelas lagi, bahwa: "A corporation aggregate consist of several members at the same time. The most frequent examples are in corporate companies. The chief peculiarity of a corporation aggregate is that it has perpetual succession (i.e., exsistence), a name, and a common seal by which its intention may be evidence; that, being merely a creation of the law, it cannot enter into a personal relation; and that, generally speaking, the mayority of the members (whose voting powers may depend on the number of their shares, or the like) have power to bind the minority in matters within the power of the corporation". Suatu kumpulan korporasi terdiri atas beberapa annggota pada waktu yang sama. Contoh yang paling sering muncul ialah pada perusahaan korporasi. keistimewaan utama kumpulan korporasi ialah memiliki rangkaian (yaitu eksistensi) berkelanjutan, sebuah nama, dan segel yang sama dimana tujuannya dapat terealisasi; bahwa dengan hanya menjadi suatu ciptaan hukum, tidak dapat memasuki hubungan personal; dan bahwa secara umum, mayoritas para anggotanya (yang kekuatan memilihnya dapat bergantung pada jumlah saham mereka) memiliki kekuasaan untuk mengikat minoritas dalam urusan-urusan kekuasaan korporasi. $^{13}$

Pengertian korporasi yang disampaikan oleh Jowitt sebagaimana diuraikan di atas, dengan jelas menunjuk pada figur badan hukum (rechtspersoon) yang mempunyai makna sebagai suatu perkumpulan atau organisasi yang oleh hukum diperlakukan layaknya orang sama seperti manusia (natuurlijke person), yaitu sebagai pengemban hak dan kewajiban, dapat memiliki kekayaan, serta memiliki kekuasaan mengikat dalam urusan kekuasaan korporasi. Sedangkan pandangan dari sisi hukum perusahaan disampaikan oleh Rudhi Prasetya, yang menyatakan bahwa badan hukum adalah subyek hukum yang mempunyai harta kekayaan sendiri yang cakap melakukan perbuatan perdata dengan akibat dari perbuatannya itu hanya dipertanggungjawabkan sampai pada jumlah harta kekayaan yang ada. ${ }^{14}$

Selanjutnya yang juga berkaitan dengan hal tersebut, Ishaq yang dalam tulisannya mengatakan bahwa :

Setiap manusia baik warga negara maupun orang asing dengan tidak memandang agama atau kebudayaannya adalah subyek hukum. Manusia sebagai pembawa hak (subyek), mempunyai hak dan kewajiban untuk melakukan tindakan hukum, seperti membuat perjanjian, menikah, membuat wasiat, dan lain-lain. Oleh karena itu, manusia oleh hukum diakui sebagai pendukung hak dan kewajiban sebagai subyek hukum. ${ }^{15}$

12 Yesmil Anwar dan Adang, Op.Cit., h. 219.

13 Ibid, h. 219.

14 Rudhi Prasetya (I), "Beberapa Segi Hukum Perusahaan”, Majalah Hukum, Nomor 2, Tahun Kedua, Yayasan Penelitian dan Pengembangan Hukum (Law Center), 1975, h. 47.

15 Ishaq, Dasar-Dasar Ilmu Hukum, Jakarta: Sinar Grafika, 2008, h. 47. 
Pada bagian selanjutnya Ishaq menambahkan :

Selain manusia pribadi sebagai subjek hukum, terdapat juga badan hukum. Badan hukum (rechtspersoon) adalah perkumpulan-perkumpulan yang dapat menanggung hak dan kewajiban yang bukan manusia, badan hukum sebagai pembawa hak yang tidak berjiwa dapat melakukan sebagai pembawa hak manusia, seperti dapat melakukan persetujuan, memiliki kekayaan yang sama sekali terlepas dari kekayaan anggota-anggotanya. ${ }^{16}$

Begitu juga dengan R. Subekti dan R. Tjitrosudibio, dalam buku Kamus Hukum mengatakan bahwa subyek hukum atau pengemban hukum adalah manusia atau badan hukum. ${ }^{17}$ Sedangkan pengertian korporasi menurut Black's Law Dictionary, adalah:

An entity (usu. A business) having authority under law to act a single person distinct from the shareholders who own and having rights to issue stock and axist indefinitely; agroup of succession of persons established in accordance with legal rules into a legal or juristic person that has legal personality distinct from the natural persons who make it up, exists indefinitely apart from them, and has the legal powers that its constitution gives it. ${ }^{18}$

Pendapat tersebut hampir sama dan senada dengan pendapat para pakar lain, dimana dinyatakan bahwa korporasi adalah buatan hukum yang ditetapkan oleh pemerintah, dimata hukum korporasi adalah orang, yang oleh karenanya korporasi dapat menggugat dan digugat atas pelaksanaan hak-hak dan tanggungjawab korporasi, sebaliknya para pemegang sahamnya tidak dapat dituntut atas pelaksanaan tersebut. Selanjutnya Stewart Kyd dalam tulisan $A$ Treatise on the Law of the Corporation yang sudah diterjemahkan kedalam bahasa Indonesia menggambarkan korporasi sebagai:

Sekumpulan individu yang bersatu dalam satu badan, dibawah satuan khusus, mempunyai rangkaian yang tak terputus dalam bentuk artificial, dan dilindungi, oleh kebijakan hukum, dengan kapasitas untuk bertindak, dalam beberapa hal, sebagai individu, khususnya dalam mengambil dan memindahkan hak milik, melakukan kontrak obligasi, dan menuntut atau dituntut, menikmati hak istimewa dan kekebalan secara umum. ${ }^{19}$

Berdasarkan pendapat para ahli sebagaimana telah diuraikan di atas, penulis mencoba menarik beberapa karakteristik korporasi sebagai berikut: 1) Korporasi merupakan suatu perkumpulan atau organisasi yang umumnya bergerak dibidang kegiatan perekonomian; 2) Korporasi merupakan badan hukum (rechtspersoon), dan dipersamakan dengan manusia (natuurlijke person) sebagai subyek hukum atau orang; 3) Korporasi sebagai pengemban hak dan kewajiban hukum; 4) Korporasi memiliki harta kekayaan sendiri terpisah dari harta kekayaan orang-orang yang tergabung didalamnya; 5) Korporasi memiliki kewenangan hukum, yakni kecakapan untuk melakukan perbuatan hukum dalam lalu lintas pergaulan masyarakat hukum melalui organ-organnya; 6) Korporasi dapat meminta dan dimintai pertanggungjawaban secara hukum, termasuk dalam hukum pidana, sehingga ia dapat dituntut dan melakukan tuntutan

\footnotetext{
Ibid, h. 49.

R. Subekti dan R. Tjitrosudibio, Kamus Hukum, Jakarta: Pradnya Paramita, 1985, h. 105.

8 Gunawan Wijaya, Risiko Hukum Pemilik, Direksi \& Komisaris, Jakarta: PT. Forum Sahabat, 2008, h. 7.

19 Stewart Kyd melalui Joel Bakan, The Corporation (Terjemahan), Kanada: FreePress, a Divison of Simon Schuster, Inc, 2004, h. 16.
} 
hukum dimuka pengadilan. Terdapat hal yang penting dari karakteristik korporasi sebagaimana di atas, penulis menggarisbawahi adanya benang merah yang teramat mendasar yang harus diperhatikan, yakni bahwa korporasi itu sesungguhnya adalah badan hukum (recthspersoon) yang tentu saja merupakan subyek hukum sebagai penyandang hak dan kewajiban. Sedangkan badan yang bukan badan hukum tentulah mempunyai karakteristik sebaliknya. Badan yang bukan badan hukum itu tidak sebagai pengemban hak dan kewajiban, tidak memiliki kewenangan hukum untuk melakukan suatu perbuatan, dan tidak memiliki harta kekayaan sendiri terpisah dari pendirinya, oleh karenanya ia bukanlah subyek hokum, sehingga ia tidak dapat dimintai pertanggungjawaban secara hukum termasuk pertanggungjawaban pidana atas segala sesuatu tindak pidana yang terjadi yang melibatkan badan yang bukan badan hukum itu. Konsekuensi dari itu semua adalah para sekutu atau pemilik dari badan yang bukan badan hukum yang bersangkutan (yang nota bene adalah natuurlijke person) bertindak selaku subyek hukum dan bertanggungjawab penuh secara pribadi atas keberadaan dan segala sesuatu yang melibatkan badan yang bukan badan hukum tersebut.

Dalam kegiatan perekonomian di masyarakat badan yang bukan badan hukum ini lebih dikenal sebagai suatu bentuk badan usaha bukan badan hukum, contohnya adalah Persekutuan Perdata atau lebih dikenal dengan istilah Maatschap yang merupakan persekutuan dengan perjanjian antara dua orang atau lebih yang saling mengikatkan diri untuk memasukkan sesuatu (inbreng) kedalam persekutuan dengan maksud membagi keuntungan yang diperoleh karenanya. Persekutuan Perdata ini diatur dalam Bab VIII Bagian Satu Buku III Pasal 1618 sampai dengan Pasal 1623 Burgerlijk Wetboek (BW). Contoh lain yang sering dijumpai dalam masyarakat adalah Firma (Fa) dan Commanditaire Vennootschap (CV). Menurut Rudhi Prasetya Firma adalah bentuk persekutuan yang diatur yang diatur dalam Bab III Bagian Satu Buku I KUHD sebagaimana dimaksud oleh Pasal 16 KUHD. Bentuk ini dalam sistem Common Law dinamakan "Partnership" ${ }^{20}$ Selanjutnya dijelaskan bahwa CV adalah bentuk persekutuan yang dalam KUHD diatur dalam Bab dan Bagian yang sama dengan Firma sebagaimana dimaksud oleh Pasal 19 KUHD. Bentuk inipun dikenal dalam sistem Common Law, yaitu dengan apa yang dinamakan “Limited Partnership". ${ }^{21}$

\section{Tindak Pidana dan Pertanggungjawaban Pidana Korporasi}

Suatu korporasi sekalipun menurut hukum perdata dapat melakukan perbuatan hukum sendiri, namun ia tidak memiliki keberadaan jasmaniah dan oleh karenanya secara riil tidak dapat bertindak, juga tidak memiliki batiniah sehingga korporasi juga tidak memiliki niat untuk melakukan tindakan atau perbuatan apapun, melainkan dengan melalui para pengurusnya. Korporasi memiliki organ-organ kepengurusan, yang sekalipun secara riil yang bertindak atau

\footnotetext{
20 Rudhi Prasetya (II), Maatschap, Firma Dan Persekutuan Komanditer, Bandung: Citra Aditya Bakti, 2004, h. 1.

21 Ibid, h. 1-2.
} 
yang melakukan perbuatan adalah para pengurus atau bahkan para pegawai korporasi, namun perbuatan hukum itu tidak mengikat kepada para pengurus atau para pegawai secara pribadi, akan tetapi mengikat korporasi itu sendiri. Seiring dengan perkembangan dunia perekonomian yang sedemikian pesat, yang lazim diikuti pula dengan gejala kriminalitas yang mengiringinya dan merupakan dampak negative dari rangkaian kelanjutan perkembangan dan pertumbuhan dunia perekonomian yang pesat tersebut, maka yang tadinya korporasi itu hanya sebatas sebagai subyek hukum perdata, kini telah pula merambah menjadikannya sebagai subyek hukum dalam hukum pidana.

Mengawali pembahasan dalam bagian ini terlebih dahulu akan dikaji tentang apa sebenarnya yang dimaksud dengan tindak pidana atau perbuatan pidana atau dalam istilah Belanda dikenal sebagai strafbaar feit. Roeslan Saleh menuliskan bahwa : "perbuatan pidana adalah perbuatan yang bertentangan dengan tata atau ketertiban yang dikehendaki oleh hukum. Syarat utama dari adanya perbuatan pidana adalah kenyataan bahwa ada aturan yang melarang". 22 Selanjutnya dengan mengacu pada pendapat Moeljatno mengenai perbuatan pidana, Roeslan Saleh juga menuliskan :

Perbuatan yang oleh aturan hukum pidana dinyatakan sebagai perbuatan yang dilarang dinamakan perbuatan pidana, juga disebut orang dengan delik. Menurut ujudnya atau sifatnya, perbuatan-perbuatan pidana ini adalah perbuatan-perbuatan yang melawan hukum. Perbuatan-perbuatan ini juga merugikan masyarakat, dalam arti bertentangan dengan atau menghambat akan terlaksananya tata dalam pergaulan masyarakat yang dianggap baik dan adil. Dapat pula dikatakan bahwa perbuatan pidana ini adalah perbuatan yang anti sosial. ${ }^{23}$

Lebih lanjut Moeljatno mengatakan: "Bahwa untuk pertanggungjawaban pidana tidak cukup dengan dilakukannya perbuatan pidana saja, akan tetapi di samping itu harus ada kesalahan, atau sikap batin yang dapat dicela, ternyata pula dalam asas hukum yang tidak tertulis : Tidak dipidana jika tidak ada kesalahan. (geen straf zonder schuld, ohne schuld keine strafe)". ${ }^{24}$ Hal senada pun telah dipertegas Moeljatno pada kesempatan lain, sebagai berikut: Perbuatan pidana hanya menunjuk kepada dilarang dan diancamnya perbuatan dengan suatu pidana. Apakah orang yang melakukan perbuatan kemudian juga dijatuhi pidana, sebagaimana telah diancamkan, ini tergantung dari soal apakah dalam melakukan perbuatan ini dia mempunyai kesalahan, sebab azas dalam pertanggungjawaban dalam hukum pidana ialah: Tidak dipidana jika tidak ada kesalahan (Geen straf zonder shculd; Actus non facit reum nisi mens sir rea). ${ }^{25}$

Pandangan Moeljatno yang memisahkan perbuatan pidana dengan pertanggungjawaban pidana (criminal responsibility) ini digolongkan sebagai pandangan yang "dualistis", sedangkan pandangan yang "monoistis" disampaikan oleh Simons dan Van Hamel dimana pengertian strafbaar feit menurut keduanya mencakup pula mengenai pertanggungjawaban

\footnotetext{
22 Roeslan Saleh, Stelsel Pidana Indonesia, Jakarta: Aksara Baru, 1983, h. 9.

Ibid, h. 13.

Ibid, h. 63.

25 Moeljatno, Asas-Asas Hukum Pidana, Jakarta: Bina Aksara, 1985, h. 153.
} 
pidana. Selanjutnya untuk dapat mempidana seseorang haruslah ditemukan adanya kesalahan yang tercermin dalam sikap batin si pembuat, oleh karenanya berkaitan dengan itu Moeljatno menambahkan secara detail bahwa untuk adanya kesalahan, terdakwa harus: a) melakukan perbuatan pidana (sifat melawan hukum); b) di atas umur tertentu mampu bertanggungjawab; c) mempunyai suatu bentuk kesalahan yang berupa kesengajaan atau kealpaan; d) tidak adanya alasan pemaaf. ${ }^{26}$

Berdasarkan uraian di atas, dalam pertanggungjawaban pidana konsep utamanya adalah ajaran tentang kesalahan atau dikenal dengan istilah "mens rea" yang dilandaskan pada azas bahwa suatu perbuatan tidak mengakibatkan seseorang bersalah, kecuali jika pikiran orang itu jahat. Berdasarkan pada azas itulah, maka untuk dapat mempidana seseorang diperlukan adanya dua persyaratan pokok, yakni: 1) adanya perbuatan yang lahiriah yang melanggar (actus rens), dan 2) adanya sikap bathin/niat yang jahat (mens rea).

Sebagai syarat yang pertama untuk mempidana seseorang adalah jelas secara lahiriah terlihat adanya tingkah laku si pembuat yang melanggar sesuatu perbuatan yang dilarang untuk dilakukan, sedangkan syarat yang kedua menunjukkan adanya sikap bathin atau keadaan jiwa dari si pembuat sehubungan dengan perbuatan yang dilakukannya itu. Dengan merujuk pendapat Moeljatno di atas maka semakin melengkapi ajaran tentang kesalahan yang tentu bermanfaat terutama untuk menentukan bagaimana menyatakan bahwa seseorang itu bersalah, hal ini penting oleh karena dalam setiap pertanggungjawaban pidana itu akan selalu ada suatu kesalahan, baik dalam bentuk kesengajaan ataupun kealpaan. Azas dalam hukum pidana yang tidak tertulis "geen straf zonder schuld" yang artinya tiada pidana tanpa kesalahan adalah azas yang sangat fundamental dalam pertanggungjawaban pidana.

Azas dalam hukum pidana modern ini lebih dikenal dengan istilah "liability without foulty" atau diterjemahkan secara bebas sebagai "pertanggungjawaban tanpa kesalahan", asas inilah yang sementara ini dipandang sebagai alternatif asas sehingga hukum pidana diharapkan dapat dan mampu mengatasi serta menanggulangi kejahatan-kejahatan inkonvesioanl yang dilakukan korporasi selaku entitas hukum, sehingga memungkinkan terhadap korporasi (rechtspersoon) dipertanggungjawabkan secara pidana sekalipun ia tidak memiliki wujud fisik dan sikap batin sebagaimana manusia (natuurlijke person). Menurut para pakar terdapat dua ajaran pokok yang menjadi landasaan pembenaran dibebankannya pertanggungjawaban pidana terhadap korporasi, yakni : 1) Ajaran Pertanggungjawaban Pidana Mutlak (Doctrine of Strict Liability); 2) Ajaran Pertanggungjawaban Pidana Pengganti (Doctrine of Vicarious Liability).

\section{Kebijakan Legislasi Telah Memperluas Batasan Korporasi}

Sebagaimana juga telah penulis sampaikan di atas, bahwa terdapat belasan undangundang diluar KUHP yang dengan tegas merumuskan batasan korporasi yang lebih luas jika dibandingkan dengan batasan yang diberikan oleh para pakar ilmu hukum mengenai korporasi,

26 Ibid., h. 164. 
contoh konkrit mengenai hal tersebut adalah Pasal 1 angka 21 UU No. 35/1999, menentukan bahwa : "Korporasi adalah kumpulan terorganisai dari orang dan/atau kekayaan, baik merupakan badan hukum maupun bukan”. Selanjutnya Pasal 130 ayat (1) dari UU No. 35/1999 tersebut menentukan bahwa: "Apabila tindak pidana sebagaimana dimaksud dalam ayat (1) dilakukan oleh korporasi, dipidana denda paling banyak $\mathrm{Rp}$ 5.000.000.000,- (lima miliar rupiah)”. Demikian juga dengan Pasal 1 angka 1dari UU Tipikor yang menentukan: "Korporasi adalah sekumpulan orang dan atau kekayaan yang terorganisasi baik merupakan badan hukum maupun bukan badan hukum”. Lebih lanjut Pasal 20 ayat (1) menentukan: "Dalam hal tindak pidana korupsi dilakukan oleh atau atas nama suatu korporasi, maka tuntutan dan penjatuhan pidana dapat dilakukan terhadap korporasi dan atau pengurusnya”.

Kebijakan legislasi yang wujudnya tertuang dalam rumusan batasan korporasi sebagaimana bunyi dari contoh-contoh ketentuan dalam undang-undang tersebut jelas membawa konsekuensi tersendiri yang mendasar mengenai apa yang dimaksudkan dengan "korporasi" sebagai suatu istilah yang dipergunakan dalam undang-undang, hal ini perlu dipertegas karena pengertian dalam konteks ini bukan saja berbeda dengan pengertian yang dibangun oleh para pakar hukum sebagai suatu doktrin, akan tetapi juga berbeda dengan pengertian korporasi dalam lingkup hukum perdata, dimana perbedaan tersebut menjadi amat mendasar karena dalam batasan yang diberikan oleh undang-undang tersebut membawa konsekuensi sebagai berikut: 1) korporasi tidak selalu merupakan badan hukum, namun dapat pula bukan badan hukum; 2) korporasi tidak selalu merupakan subyek hukum, namun bisa pula bukan subyek hukum, sehingga: a) disatu sisi ada korporasi yang merupakan penyandang hak dan kewajiban, namun disisi yang lain ada juga korporasi yang tidak menyandang hak dan kewajiban; b) disatu sisi ada korporasi yang wenang bertindak, namun disisi yang lain ada juga korporasi yang tidak memiliki kewenangan hukum untuk bertindak.

Pemberian batasan korporasi sebagaimana dalam belasan undang-undang di luar KUHP dimaksud menimbulkan konsekuensi hukum lanjutan, yakni bahwa terhadap badan yang bukan badan hukum dapat dipertanggungjawabkan secara pidana dan dapat pula dijatuhi sanksi pidana. Pandangan penulis mengatakan bahwa hal ini bertentangan dengan "kodrat" dari badan yang bukan badan hukum tersebut yang oleh hukum memang sengaja ditentukan bahwa badan yang bukan badan hukum itu bukanlah subyek hukum, dan oleh karenanya ia tidak memiliki hak dan kewajiban hukum, tidak memiliki harta kekayaan, serta tidak mempunyai kewenangan untuk bertindak, pendek kata ia bukanlah orang (person). Berbeda dengan manusia (natuurlijke person) yang secara ipso jure adalah orang, sedangkan yang dipersamakan dengan manusia sebagai orang (person) oleh hukum adalah badan hukum (rechtspersoon), dan oleh karenanya badan hukum adalah orang (person) dalam konstruksi hukum yang mengandung makna sebagai penyandang hak dan kewajiban.

Sepanjang penelusuran penulis dimasukkannya badan yang bukan badan hukum ke dalam pengertian korporasi sebagaimana rumusan dalam ketentuan undang-undang di luar 
KUHP oleh pembuat undang-undang dikarenakan pembuat undang-undang memandang bahwa tindak pidana itu tidak hanya dilakukan oleh badan hukum (rechtspersoon) saja, melainkan juga oleh badan yang bukan badan hukum. Pandangan yang demikian menurut penulis adalah keliru, karena dalam kaca mata hukum "badan yang bukan badan hukum itu (memang) tidak dapat melakukan tindakan/perbuatan apapun”, sehingga hukum memandang bahwa yang melakukan tindakan atau perbuatan itu adalah natuurlijke person-nya (manusia) yang menjadi pengurus atau pemilik dari badan yang bukan badan hukum yang bersangkutan, dan oleh karenanya pertanggungjawaban pidananya pun menjadi beban dari natuurlijke person tersebut. Hal ini berbeda jika dibandingkan dengan badan hukum (rechtspersoon) yang memang memiliki kewenangan untuk melakukan suatu tindakan/perbuatan, yang sekalipun secara materiil suatu perbuatan itu dilakukan oleh pengurus atau bahkan pegawai dari badan hukum, namun tindakan/perbuatan tersebut dipandang sebagai perbuatan dari badan hukum (rechtspersoon) yang bersangkutan, sehingga pertanggungjawaban pidananya pun menjadi beban dari badan hukum tersebut.

Berkaitan dengan itu semua sekali lagi penulis menggarisbawahi bahwa persoalan yang mendasar justru timbul ketika kebijakan legislasi menentukan dalam rumusan undang-undang mengenai batasan korporasi yang meliputi juga badan yang bukan badan hukum, terlebih terhadap badan yang bukan badan hukum ini dapat dimintakan pertanggungjawaban pidana dan dapat pula dijatuhi sanksi pidana.

Memang tidak bisa dipungkiri dengan melihat fenomena perluasan batasan korporasi tersebut ada beberapa pakar hukum yang berupaya mewadahi dengan berpendapat bahwa sesuai dengan perkembangan zaman maka pengertian korporasi saat ini mengalami perkembangan menjadi 2 (dua) macam, yakni pengertian korporasi dalam arti sempit dan dalam arti yang luas. Pengertian korporasi dalam yang arti sempit yaitu korporasi sebagai badan hukum ( $a$ corporation is a legal person). Korporasi dalam arti sempit memiliki eksistensi kewenangan hukum untuk bertindak melakukan perbuatan hukum. Eksistensi suatu korporasi sebagai badan hukum bukan muncul begitu saja, artinya bukan ada dengan sendirinya dan bukan muncul demi hukum. Korporasi sebagai badan hukum itu ada karena ada yang mendirikannya menurut ketentuan-ketentuan yang memang telah diatur dalam hukum perdata yang berlaku, sedangkan yang dapat mendirikan korporasi pada awalnya adalah manusia (natuurlijke person) dan tentu saja dapat pula badan hukum (rechtspersoon). Sedangkan pengertian korporasi dalam arti yang luas, adalah korporasi dapat berbentuk badan hukum maupun bukan badan hukum. Jadi dengan demikian seolah-olah dalam hukum pidana bukan saja badan-badan hukum seperti Perseroan Terbatas, Yayasan, Koperasi, atau perkumpulan yang telah disahkan sebagai badan hukum yang digolongkan sebagai korporasi menurut hukum perdata, akan tetapi juga Maatschap (Ma.), Firma (Fa.), Persekutuan Komanditer (CV), Usaha Dagang (UD) atau bahkan sekumpulan orang yang terorganisasi dan memiliki pimpinan serta melakukan kegiatan-kegiatan tertentu juga termasuk dalam pengertian korporasi. 
Kebijakan legislasi yang memperluas pengertian "korporasi" untuk menggambarkan korporasi sebagai suatu badan hukum disatu sisi, dan badan yang bukan badan hukum disisi yang lain, kiranya menjadi penting untuk dibahas dan diluruskan kembali agar tidak menimbulkan kesesatan yang lebih mendalam, baik pada tataran law in the book terutama dalam teori ilmu hukum maupun dalam penerapannya pada praktik hukum sehari-hari, mengingat badan yang bukan badan hukum dalam konteks hukum perdata sebagai bidang hukum yang membidaninya telah menentukan bahwa terhadap badan yang demikian itu tidak dapat dimintai pertanggunganjawab dalam hukum, karena ia bukanlah orang.

\section{Dampak Perluasan Batasan Korporasi}

Dengan perluasan batasan korporasi sebagaimana ditentukan dalam berbagai undangundang di luar KUHP tersebut, maka terdapat penambahan jenis korporasi, karena disamping adanya korporasi yang dalam arti sesungguhnya yakni sebagai badan hukum (rechtspersoon) disatu sisi, dan disisi yang lain ada juga korporasi yang hanya sekedar sekumpulan orang dan atau kekayaan yang terorganisasi sekalipun itu bukan badan hukum. Sehingga jika dirinci jenis-jenis korporasi meliputi: 1) Korporasi yang merupakan badan hukum, terdiri dari : Perseroan Terbatas (PT); Yayasan; Koperasi; Perusahaan Perseroan (Persero); Perusahaan Umum (Perum); Perusahaan Daerah (PD); 2) Korporasi yang bukan badan hukum, meliputi : Persekutuan Komanditer / Commanditarire Vennootschap (CV); Firma (Fa); Persekutuan Perdata (Maatschap); Perusahaan Perorangan Usaha Dagang (UD); Lain-lain bentuk perkumpulan orang dan atau kekayaan yang terorganisir namun bukan $\mathrm{CV}, \mathrm{Fa}, \mathrm{Ma}$, maupun UD.

Kenyataan di Indonesia, disamping adanya badan-badan usaha formil yang bukan badan hukum sebagaimana telah disebutkan di atas, juga terdapat banyak perkumpulan orang dan atau kekayaan yang terorganisasi yang bukan badan hukum dan bahkan tidak tercatat secara formil sebagai suatu perkumpulan atau organisasi, sehingga dengan kebijakan legislasi yang memperluas pengertian korporasi sebagai "perkumpulan orang dan atau kekayaan yang terorganisasi dan bukan badan hukum" tersebut maka secara gramatikal turut menjadikan "perkumpulan atau organisasi-organisasi" semacam itu masuk dalam pengertian korporasi. Hal tersebut tentu saja membuat makna korporasi menjadi jauh melebar, dan kabur serta ada kecenderungan keluar dari konteks awal makna korporasi itu sendiri yang sebenarnya hanya sebatas badan hukum yang bergerak dibidang perekonomian dalam masyarakat.

Kebijakan legislasi dalam rumusan undang-undang yang demikian ini merupakan bola-liar karena "perkumpulan orang dan atau kekayaan yang terorganisasi dan bukan badan hukum" dapat ditafsirkan sebagai apapun, dan menimbulkan ketidakpastian mengenai subyek tindak pidananya sehingga bukan saja akan menyulitkan dalam penerapannya, namun juga memunculkan kerancuan hukum. Ini semua terjadi karena dari perluasan batasan tersebut muncul adanya ketidaksinkronan (out of system) antara bidang hukum yang mengatur hal-hal yang bersifat fundamental mengenai apa dan bagaimana suatu badan hukum dan badan yang 
bukan hukum itu dalam hukum perdata, dengan kebijakan perluasan batasan itu sendiri yang nota bene menjadi aturan yang ditentukan dalam undang-undang. Ketidaksinkrunan tersebut akan amat dirasakan ketika menyangkut masalah pertanggungjawaban hukum (termasuk juga pertanggungjawaban dalam hukum pidana) terhadap korporasi terutama badan yang bukan badan hukum, oleh karenanya penulis berpendapat perlu adanya redefinisi mengenai batasan korporasi tersebut sehingga kembali lagi bahwa yang dimaksud dengan korporasi tidak lain adalah badan hukum, sebab hanya badan hukumlah (selain manusia) yang bisa dipertanggungjawabkan dalam hukum, termasuk dalam hukum pidana.

\section{Mempertanggungjawabkan Secara Pidana Badan Yang Bukan Badan Hukum}

Terdapat perbedaan karakteristik yang fundamental antara badan hukum (rechtspersoon) dengan badan yang bukan badan hukum, oleh karenanya kebijakan legislasi yang tertuang dalam rumusan ketentuan undang-undang yang mempertanggungjawabkan secara pidana badan yang bukan badan hukum sebagaimana telah diuraikan di atas sudah tentu menjadi persoalan yang mendasar.

Sehubungan dengan persoalan tersebut penulis mencoba mengaktualisasikan contoh badan usaha yang bukan badan hukum sebagai suatu model bahasan agar didapat gambaran yang lebih konkret mengenai hal tersebut. Berdasarkan pertimbangan bahwa bentuk badan usaha dibawah ini lebih merupakan suatu wadah kegiatan usaha yang teroganisir dan hampir mendekati bentuk dengan yang berbadan hukum, maka penulis memilih Persekutuan Komanditer (CV) sebagai modelnya.

Persekutuan Komanditer (Commanditaire Vennootschap / CV), diatur dalam Kitab Undang-undang Hukum Dagang (KUHD atau WvK) khususnya Pasal 19-35, sedangkan yang dimaksud dengan Persekutuan Komanditer atau ada pula yang menyebutnya dengan istilah Perseroan Komanditer adalah:

Perseroan dengan setoran uang dibentuk oleh satu atau lebih anggota aktif yang bertanggung jawab secara renteng di satu pihak dengan satu atau lebih orang lain sebagai pelepas uang dilain pihak. Para pelepas uang ini disebut pesero anggota pasif, commanditaris, sleeping partner, tidak bertanggung jawab lebih dari nilai sahamnya masing-masing. Sedangkan anggota pesero yang mengurusi sehari-hari CV disebut pesero aktif atau sering juga disebut dengan complementaris. ${ }^{27}$

Apabila di dalam CV terdapat lebih dari seorang sekutu kerja (sekutu aktif) maka berlakulah ketentuan Pasal 19 ayat (2) KUHD yang menentukan bahwa: "Suatu persekutuan dapat juga pada waktu yang sama berwujud persekutuan dengan firma terhadap sekutu-sekutu yang memakai nama bersama dan persekutuan secara peminjaman uang bagi si pelepas uang." Melihat ketentuan tersebut penulis dapat memahami dan setuju dengan apa yang dikatakan oleh Rudhi Prasetya bahwa manakala dalam CV ada lebih dari seorang sekutu kerja, maka dalam hal ini hubungan diantara para sekutu kerja yang ada adalah hubungan firma, artinya para sekutu

27 Sentosa Sembiring, Hukum Dagang. PT. Citra Aditya Bakti, Bandung: 2008, h. 44. 
kerja itu satu terhadap yang lain diantara sesama sekutu kerja bertanggungjawab tanggungmenanggung renteng sebagaimana Pasal 18 KUHD. ${ }^{28}$ Pada dasarnya CV juga merupakan persekutuan perdata oleh karenanya ketentuan-ketentuan sebagaimana dalam Kitab UndangUndang Hukum Perdata (BW) secara umum juga diberlakukan bagi CV yaitu Pasal 1618 BW sampai dengan Pasal 1652 BW, dan Pasal 1233 BW sampai dengan Pasal 1456 BW.

Berdasarkan pendapat para pakar dan segala pengaturannya mengenai CV sebagaimana terurai di atas, didapat unsur-unsur penting Persekutuan Komanditer sebagai berikut: 1) CV merupakan persekutuan perdata yang di dalamnya terdapat unsur kerja sama, dengan modal yang berasal dari pemasukan (inbreng) yang dapat berupa uang, barang atau bahkan tenaga, dan bertujuan mendapat serta membagi keuntungan; 2) CV didirikan untuk menyelenggarakan perusahaan / kegiatan komersial; 3) CV mempunyai dua macam sekutu, yakni: a) Sekutu aktif / sekutu komplementer, yaitu sekutu yang bertindak sebagai pengurus, dapat mengikatkan Persekutuan Komanditer (CV) dengan pihak ketiga dan bertanggung jawab secara tanggung renteng sampai pada kekayaan pribadi. b) Sekutu pasif / sekutu komanditer), yaitu sekutu yang hanya memberikan pemasukan (inbreng) dan tidak ikut dalam mengurus persekutuan, dan tanggung jawabnya sebatas pada modal yang dimasukkan; 4) CV hanyalah suatu bentuk usaha bersama yang bukan merupakan badan hukum; 5) CV juga bukan subyek hukum yang merupakan pengemban hak dan kewajiban; 6) CV tidak memiliki harta kekayaan tersendiri yang terpisah dari kekayaan para sekutunya; 7) CV tidak mempunyai kewenangan hukum.

Memperhatikan bahwa CV sebagai suatu badan usaha yang bukan merupakan badan hukum tidak memiliki kewenangan bertindak, dan yang memiliki kewenangan untuk melakukan perbuatan hukum dalam CV adalah sekutu aktif atau sekutu komplementer secara pribadi yang notabene adalah manusia (natuurlijke person), oleh karenanya menjadi logis apabila terjadi suatu pelanggaran hukum baik dalam konteks hukum perdata maupun hukum pidana yang dipertanggungjawabkan adalah sekutu aktif atau sekutu komplementer secara pribadi. Sehingga dalam penerapan sanksi pidananya pun para sekutu tersebut dapat diterapkan sanksi-sanksi pidana sebagaimana Pasal 10 KUHP. Berseberangan dengan uraian contoh di atas, adalah pada kenyataannya kebijakan legislasi yang tertuang dalam rumusan pasal-pasal perundang-undangan diluar KUHP menentukan mengenai batasan korporasi meliputi korporasi yang berbadan hukum disatu sisi, dan disisi yang lain korporasi yang bukan badan hukum yang keduanya oleh undang-undang tertentu tersebut sama-sama dapat dipertanggungjawabkan dalam hukum pidana dan dapat pula dipidana.

Menurut penulis, mempertanggungjawabkan secara pidana badan yang bukan badan hukum, ditinjau dari sudut pandang hukum sebagai suatu sistem merupakan suatu pertentangan antar kaidah hukum, dimana kaidah hukum yang terkandung dalam hukum perdata yang menentukan bahwa badan yang bukan badan hukum bukanlah subyek hukum sehingga tidak dapat dimintai pertanggungjawaban secara hukum (termasuk dalam lingkup hukum pidana),

28 Rudhi Prasetya (II), Op.Cit., h. 4. 
namun disisi yang berlawanan dihadapkan pada kebijakan legislasi sebagaimana dimaksud dalam berbagai undang-undang tersebut yang menentukan bahwa terhadap badan yang bukan badan hukum juga dapat dipertanggungjawabkan dalam hukum pidana sama dengan badan hukum.

Sebenarnya apa yang penulis sampaikan di atas sama halnya seperti di Inggris, dimana menurut hukum Inggris korporasi merupakan badan hukum (a corporation is a legal person), dan secara pidana dapat dituntut atau bertanggungjawab meskipun tidak memiliki wujud fisik dan tidak dapat bertindak atau berfikir, kecuali melalui direksi atau karyawannya. Berbeda dengan badan yang bukan badan hukum Michael J Allen dalam Textbook On Criminal Law mengatakan: "At common law an unincorporated association is not a legal person and therefore not subject to criminal liability". ${ }^{29}$ Sebagaimana juga dikutip oleh Dwidja Priyatno yang menyatakan bahwa menurut "common law" assosiasi yang tidak diinkorporasikan (unincorporated association) bukanlah badan hukum, sehingga tidak dapat dipertanggungjawabkan secara pidana. ${ }^{30} \mathrm{Hal}$ tersebut dapat penulis pahami oleh karena yang merupakan kunci utama dalam tradisi common law Inggris adalah sebuah sistem hukum berbasis perkara yang berfungsi melalui penalaran logis, serta tidak ada pembedaan hukum privat/publik secara struktural atau substantif seperti yang terdapat di dalam sistem-sistem civil law, ${ }^{31}$ oleh karenanya hal tersebut menjadi amat logis dalam konteks korporasi diartikan sebagai badan hukum (coparation is a legal person), sehingga konsekuensinya terhadap badan yang bukan badan hukum (unincorporated association) tidak dapat dimintai pertanggungjawaban secara hukum termasuk dalam hukum pidana. Contoh yang mudah ditemukan dari badan yang bukan badan hukum sebagaimana telah disinggung di atas adalah Maatschap (Ma), Firma (Fa) dan Commanditaire Vennootschap (CV) atau Persekutuan Komanditer, oleh karenanya penulis sependapat dengan Rudhy Prasetya yang dalam tulisannya mengatakan bahwa:

Menurut hukumnya, Maatschap, Firma dan CV bukanlah badan hukum sebagaimana Perseroan Terbatas (PT), Perkumpulan, dan Yayasan umpamanya. Dalam sistem common law, partnership dan limited partnership tidak pula tergolong sebagai badan hukum (it does not have a legal existence separate and apart from the persons associated together to create it). ${ }^{32}$

Penulis berpendapat, bahwa semestinya seperti itulah hukum Indonesia memperlakukan badan yang bukan badan hukum. Sebagaimana juga telah disinggung pada bagian terdahulu bahwa korporasi sebagai suatu badan hukum (rechtspersoon) oleh hukum dipandang mempunyai kedudukan yang menyamai kedudukan individu manusia (natuurlijke person) sebagai subyek hukum yang mengemban hak dan kewajiban, sehingga adalah wajar sebagai subyek hukum jika melakukan suatu perbuatan pidana hendak dipertanggungjawabkan pula secara pidana dan

29 Michael J Allen, Textbook On Criminal Law, Oxford University Press 2005, p. 229.

30 Dwidja Priyatno, Op.Cit, h. 238.

31 Peter de Cruz, Perbandingan Sitem Hukum Common Law, Civil Law dan Socialist Law (Terjemahan dalam Bahasa Indonesia), Bandung: Nusa Media, 2010, h. 146.

32 Rudhy Prasetya (II), Op.Cit, h. 6. 
bahkan hingga dijatuhi sanksi pidana sekalipun, tidaklah terlalu menjadi persoalan yang pelik sepanjang kebijakan legislasi pembentuk undang-undang menentukan demikian. Hal tersebut dari sisi keadilan tentunya boleh dibilang adil dalam arti siapa yang berbuat maka ia harus bertanggungjawab, namun bagaimana dengan badan yang bukan badan hukum seperti misalnya firma $(\mathrm{Fa})$, atau Comanditaire Vennootschap $(\mathrm{CV})$, mereka bukanlah badan hukum dan bukan pula sebagai subyek hukum, tidak mempunyai kewenangan bertindak, dan tidak mempunyai kekayaan sendiri yang terpisah dari pendirinya, bahkan mereka badan yang bukan badan hukum ini bukan siapa-siapa dan tiba-tiba harus bertanggungjawab secara pidana, serta dapat pula dijatuhi sanksi pidana denda yang umumnya lebih berat jika dibandingkan dengan ancaman pidana yang ditujukan kepada subyek hukum natuurlijke person.

Sebagai contohnya adalah apa yang ditentukan dalam Pasal 59 ayat (3) Undang-Undang Nomor: 5 Tahun 1997 tentang Psikotropika (UU No. 5/1997), yang menentukan: “Jika tindak pidana dalam pasal ini dilakukan oleh korporasi, maka disamping dipidananya pelaku tindak pidana, kepada korporasi dikenakan pidana denda sebesar Rp 5.000.000.000,- (lima miliar rupiah)”. Demikian juga ketentuan dalam Pasal 52 ayat (4) Undang-Undang Nomor : 11 Tahun 2008 tentang Informasi Dan Transaksi Elektronik (UU No. 11/2008), yang menentukan: "Dalam hal tindak pidana sebagaimana dimaksud dalam Pasal 27 sampai dengan Pasal 37 dilakukan oleh korporasi dipidana dengan pidana pokok ditambah dua pertiga”. Juga dalam ketentuan Pasal 201 ayat (1) Undang-Undang Nomor: 36 Tahun 2009 tentang Kesehatan (UU No. 36/2009), yang menentukan: "Dalam hal tindak pidana sebagaimana dimaksud dalam pasal 190 ayat (1), Pasal 191, Pasal 192, Pasal 196, Pasal 197, Pasal 198 dan Pasal 200 dilakukan oleh korporasi, selain pidana penjara dan denda terhadap pengurusnya, pidana yang dapat dijatuhkan terhadap korporasi berupa pidana denda dengan pemberatan 3 (tiga) kali dari pidana denda sebagaimana dimaksud dalam Pasal 190 ayat (1), Pasal 191, Pasal 192, Pasal 193, Pasal 196, Pasal 197, Pasal 198, Pasal 199 dan Pasal 200”.

Berdasarkan ketentuan-ketentuan tersebut jelas bahwa tuntutan dan ancaman pidana disamping dikenakan terhadap pengurus juga pidana denda yang lebih berat dikenakan terhadap korporasi meskipun korporasi itu adalah bukan badan hukum. Dapat dibayangkan bahwa andaikata pun sanksi pidana denda yang lebih berat terhadap korporasi yang bukan badan hukum tersebut dapat dibayar dan diselesaikan oleh sekutu aktifnya, namun sekutu aktif yang bersangkutan secara pribadi juga dipertanggungjawabkan dalam hukum pidana berkaitan dengan persoalan yang sama, artinya sekutu aktif yang umumnya adalah juga pendiri atau pemilik dari korporasi yang bukan badan hukum itu menjadi diadili dan dipidana dua kali atas persoalan yang sama, oleh karenanya bukan saja menjadi nebis in idem namun jika ditinjau dari sisi keadilan sebagaimana dimaksud dalam teori-teori tentang keadilan khususnya teori etis yang menyatakan bahwa hukum semata-mata bertujuan untuk keadilan, dan isi hukum ditentukan oleh keyakinan kita yang etis tentang yang adil dan tidak, atau dengan perkataan lain tujuan hukum menurut teori ini adalah merealisir atau mewujudkan keadilan, maka norma 
hukum sebagaimana terkandung dalam contoh ketentuan-ketentuan tersebut jelas tidak adil dan bahkan telah "memperkosa" prinsip-prinsip hukum yang berkaitan dengan karakteristik dari badan yang bukan badan hukum tersebut.

Selanjutnya dari sudut pandang kemanfaatan hukum, ditemukan adanya teori utilitis yang menyatakan bahwa pada hakekatnya tujuan hukum adalah manfaat dalam menghasilkan kebahagian yang terbesar bagi jumlah orang yang terbanyak, menurut penulis juga tidak tercapai karena memang faktanya ketentuan-ketentuan yang menyangkut bidang kajian kejahatan korporasi ini sejak pertama kali dimunculkan dalam perundang-undangan di Indonesia hingga saat ini dapat dikatakan tidak pernah diterapkan dalam praktek penegakan hukum sehari-hari, sedangkan menyangkut masalah kepastian hukum sebagaimana juga telah penulis bahas dalam uraian terdahulu dimana disatu sisi badan yang bukan badan hukum itu adalah bukan subyek hukum, namun disisi yang lain kebijakan legislasi yang tertuang dalam ketentuan undangundang tertentu di luar KUHP tersebut telah dengan tegas mempertanggungjawabkan badan yang bukan badan hukum secara pidana, hal ini menimbulkan dualisme didalam pengaturan mengenai pertanggungjawaban hukum (termasuk pertanggungjawaban dalam hukum pidana) terhadap korporasi khususnya korporasi yang bukan merupakan badan hukum, dimana dualisme itu dengan jelas menunjukkan adanya pertentangan antara apa yang diatur dalam hukum perdata khususnya mengenai badan yang bukan badan hukum disatu sisi dengan pengaturan sebagaimana dalam ketentuan perundang-undangan tertentu di luar KUHP yang mempertanggungjawabkan secara pidana badan yang bukan badan hukum disisi yang lain, disinilah letak dari ketidakpastian hukum itu muncul sehingga terjadi ketidaksinkrunan antar sub sistem hukum yang ada, dan tentu saja tidak boleh dibiarkan berlarut-larut tanpa kejelasan akan keadilan, kemanfaatan serta kepastian hukum.

\section{Kesimpulan}

Berdasarkan semua uraian di atas, maka dapat disimpulkan bahwa terdapat karakteristik yang berbeda antara badan hukum (rechtspersoon) dengan badan yang bukan badan hokum. Perbedaan karakteristik tersebut, menyebabkan adanya perbedaan dalam pertanggungjawaban pidananya, hal tersebut terjadi karena letak beban dari pertanggungjawabannya itu sendiri, dimana untuk badan hukum beban tanggungjawabnya berada pada badan hukum itu sendiri (recthspersoon), sedangkan untuk badan yang bukan hukum beban tanggungjawabnya berada pada para sekutu atau pesero atau pemilik secara pribadi yang nota bene adalah manusia (natuurlijke person), selain itu hal tersebut terjadi karena adanya prinsip-prinsip hukum yang melatarbelakangi terbentuknya masing-masing badan hukum dan badan yang bukan badan hukum tersebut. Prinsip-prinsip hukum dimaksud terutama yang berasal dari lingkup hukum perdata yang memang sejak awal telah membentuk karakter dari masing-masing badan itu.

Kemudian dapat dikatakan juga bahwa telah terjadi ketidaknalaran bagi hukum (unlogic for the law) dalam mempertanggungjawabkan secara pidana terhadap korporasi, 
dimana korporasi diartikan sebagai kumpulan orang dan atau kekayaan yang terorganisasi baik merupakan badan hukum maupun bukan badan hukum sebagaimana yang telah diatur dalam berbagai undang-undang diluar KUHP. Oleh karenanya menjadi suatu hal yang penting untuk me-review konsep pertanggungjawaban pidana korporasi, sekarang.

\section{Daftar Bacaan}

Abidin F., Zainal, "Pertanggungjawaban Terhadap Delik-Delik Ekonomi” Jurnal 1955

Adil, Soetan K. Malikoe, Pembaharuan Hukum Perdata Kita. Jakarta: Pembangunan,

Allan J Michael, Textbook On Criminal Law, Oxford University Press 2005.

Amrullah, M. Arief, Kejahatan Korporasi. Malang: Bayumedia Publishing, 2004.

Arief, Barda Nawawi, Bunga Rampai Kebijakan Hukum Pidana, Perkembangan Penyusunan KUHP Baru. Jakarta: Kencana Prenada Media Group, 2008.

, Perbandingan Hukum Pidana. Jakarta: RajaGrafindo Persada, 2002.

Bakan, Joel, The Corporation, Kanada: FreePress, a Divison of Simon Schuster, Inc. 2004.

Bruggink, J.J. H. (alih Bahasa Arief Sidharta), Refleksi Tentang Hukum. Bandung: Citra Aditya Bakti, 1999.

Carraso, Cynthia E. and Dipee, Michael K., "Corporate Criminal Liability" The American Criminal Law Review, Georgetown University Law Center, Chicago 1999.

Darmabrata, Wahyono dan Ari Wahyudi Hertanto, "Implementasi Good Corporate Governance Dan Komisaris Perseroan Terbatas” Jurnal Hukum Bisnis, Volume 22 Nomor 6, 2003.

Departemen Pendidikan Nasional, Kamus Besar Bahasa Indonesia, Edisi Keempat, Jakarta: Gramedia Pustaka Utama, 2008.

Garner, Bryan A., Black Law Dictionary, Ninth Edition, USA: West Thomson Reuter

Geis, Gilbert, Joseph FC DiMento, Empirical Evidence and The Legal Doctrine

Gerber, Jurg and Jensen Eric. L, with the collaboration of Kubena Jilleta. L Encyclopedia of White Collar Crime. London: Greenwood Press, Westport, Connecticut, 2007.

Gerry, A. Ferguson, ”Criminal Liability And Sentenceing Of Corporations”.

Hadjon, Philipus M., dan Tatiek Sri Djamiati, Argumentasi Hukum, Yogyakarta: Gadjah Mada University Press, 2005. 
Hukum dan Pembangunan, Tahun Ke-35 No. 1, Januari 2005.

Hutchinson, Terry, Researching and Writing in Law. Sydney: Lawbook Co. 2002.

Ibrahim, Johannes, Hukum Organisasi Perusahaan, Pola Kemitraan Dan Badan Hukum, Bandung: Refika Aditama, 2006.

Jamieson, Katherine M., The Organization of Corporate Crime. California: SAGE Publications Inc. 1994.

Jobb, Dean, Who's responsible?. Toronto: Canadian Business, 2003.

Jurnal Ilmiah FH Unair. Vol. 34 No. 1, Januari 2010.

Kebijakan Hukum Pidana” Yuridika, Vol. 18, No. 1, Januari-Pebruari 2003 :

Kelsen, Hans, Pengantar Teori Hukum. Bandung: Nusa Media, 2008.

Lansing, Paul and Donald Hatfield, Corporate Control Through the Criminal

Maclean's, Steve Maich, Presumptions of Guilt. Toronto: Rogers Publishing Limited, 2005.

Marzuki, Peter Mahmud, Penelitian Hukum. Jakarta: Kencana Prenada Media Group, 2005. , Pengantar Ilmu Hukum, Jakarta: Kencana Prenada Media Group, 2008.

McLeod, Thomas Ian, Legal Method. London: Macmillan Press Ltd., 1996.

Mertokusumo, Sudikno, Mengenal Hukum (Suatu Pengantar). Yogyakarta: Liberty, 1988.

Moeljatno, Azas-Azas Hukum Pidana. Jakarta: Bina Aksara, 1985. , Kitab Undang-Undang Hukum Pidana. Jakarta: Bina Aksara, 1985.

Montesquieu, The Spirit of Laws. Bandung: Nusamedia, 2007.

Muhammad, Abdulkadir, Hukum Perusahaan Indonesia, Bandung: Citra Aditya Bakti, 2006.

Mulyadi, Lilik, Seraut Wajah Putusan Hakim Dalam Hukum Acara Pidana Indonesia Bandung: Citra Adtya Bakti, 2010.

Novianto, Widodo Tresno, "Korporasi Sebagai Subyek Tindak Pidana Korupsi of Corporate Criminal Liability. USA: University of Texas, Austin School of Law Publications, 2003.

Pertanggungjawaban Pidana Tanpa Kesalahan” Jakarta: Kencana Prenada Media Group, 2008. 
Priyatno, Dwidja, Kebijakan Legislasi Tentang Sistem Pertanggungjawaban Pidana Korporasi di Indonesia. Bandung: Utomo, 2009.

Sahetapy, J.E., Kejahatan Korporasi. Bandung: Eresco, 1994

Sholehuddin, M., Sistem Sanksi Dalam Hukum Pidana. Jakarta: Raja Grafindo Persada, 2003.

Sidharta, Bernard Arief, Refleksi Tentang Struktur Ilmu Hukum. Bandung: Mandar Maju, 2000.

Sjahdeini, Sutan Remy, Pertanggungjawaban Pidana Korporasi, Jakarta: Grafiti Pers, 2007.

Suarta, Dewa, "Pertanggungjawaban Tindak Pidana Korporasi Di Indonesia”

Suparni, Niniek, Eksistensi Pidana Denda Dalam Sistem Pidana Dan Pemidanaan, Jakarta: Sinar Grafika, 2007.

Undang-Undang” Pidato Pengukuhan Guru Besar Fakultas Hukum Universitas Airlangga Surabaya 2008.

Waluyo, Bambang, Pidana dan Pemidanaan, Jakarta: Sinar Grafika, 2004.

Wells, Celia, Corporations and Criminal Resposibility, Second Edition, Juridische Bibliotheek Universiteit Utrecht, 2001.

Wijaya, Gunawan, Risiko Hukum Sebagai Direksi, Komisaris \& Pemilik PT, Jakarta: Forum Sahabat, 2008.

Yuridika Vol. 14 No. 4, Juli-Agustus 1999.

Zweigert, Konrad and Hein Kotz, Introduction To Comparative Law. Oxford: Clarendon Press, 1998. 